\title{
Evaluation of Major Land Uses in Tertiary Institution: A Case Study of Obafemi Awolowo University Ile Ife, Nigeria
}

\author{
Olusola Oladapo Makinde', Muhammad Ridwan', M. Yoserizal Saragih ${ }^{3}$ \\ ${ }^{I}$ Department of Architecture, Ladoke Akintola University of Technology, Ogbomoso, Nigeria \\ ${ }^{2,3}$ Universitas Islam Negeri Sumatera Utara, Indonesia \\ makindeolusola2012@yahoo.com
}

\section{Abstract}

Land uses involve important economic and environmental implications for policy issues. To monitor the trend in land use in tertiary institution, statistics on land use overtime must be developed. The study investigated the various uses of land in Obafemi Awolowo University (OAU); determine their size base on an area of land covered, and determine the major land uses in $O A U$ to inform planners on the basic tool for institutional physical development and insight for enhancing planning. The Google earth pro and OAU base map were subsequently used to enhance visual interpretation and aid the identification and mapping of the various land use in the study area. Findings from the study show that the total landed area is 5,609 hectares. The undeveloped area constitutes more than half of the total landed area with 3382 hectares (60\%). A total of 1,216 hectares of land was set aside for agriculture purposes and research, the major land uses is residential with 456.74 hectares (45.18\%); institutional uses had 257.02 hectares (25.42\%); other uses had 115.97 hectares (11.47\%); water bodies had 83.5 hectares (8.26\%); transportation had 56.33 hectares (5.57\%); commercial had 38.36 hectares (3.79\%); and Recreation had 3.08 hectares $(0.31 \%)$, the least proportion of land use. The study concluded that land use should be monitored, regulated, and controlled by the various relevant planning and monitoring agencies of the university.

Keywords

land uses, tertiary institution; evaluation; Ngeria

\section{Introduction}

The land is an important commodity for daily use and many purposes. One of the most significant natural resources on which all of man's activities are depended upon is the land, and a thorough knowledge of it, which includes the land use/land cover, is very much vital for several planning and management activities. For several decades, the land has continued to influence the lives of Nigerians socially, economically and politically. A complex set of relationships has emerged among groups in the process of using land (Famoriyo, 2007). The term "land use" relates to human activity or economic function associated with a specific piece of land. Globally, urban centres are made up of different land uses. These include residential, commercial, public, recreational, industrial and circulation or transport land uses among others. In different parts of the world, the proportion of land allocated to various land uses vary tremendously over time and space depending on their level of development and compliance with the planning policy. 
Similarly, the priority for allocation also depends on the use to which the land will be put. For instance, Adetunji (2014) cited Clark et al (2006) land-use types in Canada, which was classified into six categories, with the residential occupying the largest proportion $(40 \%)$, closely followed by transportation (32\%), public /institutional (10\%), open space $(7 \%)$, industrial $(6 \%)$, while commercial land use occupies $(5 \%)$ the least proportion of land use. The urban land-use zoning in the advanced countries of the world especially in Nigeria tertiary institution. This did not exist in some of the developing countries of the world, most especially in Asian and African countries where mix land use predominated. It is against this background that this study is designed to examine the various uses of land in OAU, Ile-Ife, Nigeria and determine the major use. This study aims to investigate the various uses of land in Obafemi Awolowo University to determine the major use of land in the institution. The specific objectives are to; investigate the various uses of land in the study area; determine their size base on the area of land covered, and to determine the major use of land in OAU.

Obafemi Awolowo University has witnessed remarkable expansion, growth and developmental activities in the area of the building and infrastructural development and in many other activities since its inception in 1962 just like many other tertiary institutions in Nigeria. This has therefore resulted in increased land consumption and a modification and alterations in the status of her land use over time without any detailed and comprehensive attempt to evaluate this status as it increases over time to determine the land consumption rate and also make attempt to predict same and the possible changes that may occur in this status so that planners can have a basic tool for planning. Land use and land-use changes involve important economic and environmental implications for policy issues. And to monitor the trend in land use, statistics on land use overtime must be developed. This research presents the major land uses in Obafemi Awolowo University and the study is necessary to avoid the associated problems of a growing and expanding university like many others in the world.

\section{The Study Area}

Obafemi Awolowo University (OAU) is a Federal Nigerian University, situated in Ile Ife, Osun state Nigeria, which was established in 1962 (Adetokunbo, 2010). In 2014, a two hundred (200) member stakeholders' forum was inaugurated to review the master plan with a mandate to expose the extent of existing development and also access the adequacy and physical condition of residential, commercial, academics and recreational environments. The review is been undertaken by a Lagos-based Town Planning Firm, Messrs Femi Olomola and company and currently work is ongoing on the master plan (Njoku and Kumolu, 2014). The existing land use system of the university is 11, 855 hectares of land out of which a land area of about 5,609 hectares was captured in the first master plan and an additional area of about 6,256 hectares was also acquired around 1973 for further development. Out of the 5,609 hectares of land, 1,011 hectares have been developed and 1216 hectares was set aside for the Teaching and Research farm. The university comprises the central campus, the student residential areas, the staff quarters and a teaching and research farm. The central campus comprises the academic, administrative units and service centres while the student residential area is made up of 9 undergraduate hostels and a postgraduate hall of residence. There is a power station, a dam and a good treatment plant. Figure 1 below shows the map of Obafemi Awolowo University, Ile-Ife. 


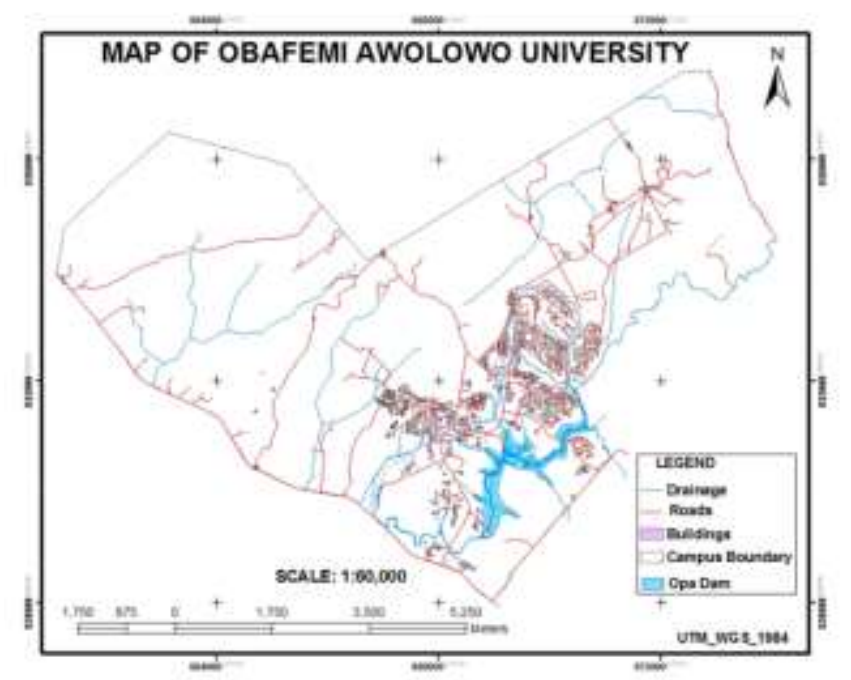

Figure 1. Map of Obafemi Awolowo University, Ile-Ife

Source: https://www3.laurentian.ca/rcgt-cjtg/wp-content/uploads/2019/09/Figure_1.png

\section{Review of Literatures}

In the urban and rural areas of all society land, is requires for various uses. It is a major factor of production and a vital element in the socio-economic development of any country or society (FMH\&UD, 2006). Consequently, as communities grew in size there is always an increased competition as well as demand for land for different purposes (Aribigbola, 2008). For effective planning, layouts of various land use such as residential, commercial. Industrial, open spaces and recreation, institutional uses, agricultural uses among others are undertaken to standardize and organize physical developments and ensure harmonious growth (Aribigbola, 2008, Izharsyah and Lubis, 2020).

Economic functions determine land use classification systems and can be logical according to the activities evidence on the ground with a place. In different countries, based on their purpose, many classification systems have been developed. For instance, American Planning Association developed land-based classification standard; the National Land use Database (NLUD) land use classification version 3.3 which was proposed by the British authority with 13 divisions and 51 classes (Harrison and Garland, 2001); the Chinese Authority presented the National Standard for Urban Land Use Classification (Zhan et al, 2000). In this research, the land use classification we are talking about concerns the need for investigating and monitoring how Obafemi Awolowo University land is used for various purposes. This is different from zoning land use coding where particular land use is used to specify the preference for certain uses of a particular land parcel, although similar land use classification system is applied in both cases. In general, the type of classification used for this research is based mainly on the need of planners and other related businesses because the other classifications are too detailed and requiring additional information. Since we are interested in land use classification system in Obafemi Awolowo University, we consider only land-use types found in the institution. 


\subsection{Residential Uses}

This is where people live; which can involve family dwellings of various sorts based on residential density. Residential land use as defined by Karen, (1994) can be land use for low density consisting of single-family homes, semi-detached homes, and duplexes, also medium density which can be townhouses and low-rise apartments while high density consists of high-rise apartments and private and common open space while the most intensive residential land uses are associated with clusters of apartment buildings, which can support extremely large densities of human populations. Thomson, (2013) also viewed residential land uses to comprises of single-family residences, suburban homestead, or any number of other designations which cover homes, apartments, duplexes, trailer parks, and condominiums.

\subsection{Commercial Uses}

Commercial lands use are those used predominantly for the sale of products, services and for commercial activities, which includes any land use that is used for buying, selling, or trading goods and services which provide opportunities for a broad range of retail, professional offices and other uses intended to meet the need of the society, which is mostly located along the main road, major highways, access routes to cities, freeway corridors, and in urban central business districts (Karen, 1994). However, there are several types of commercial land use which is usually dependent upon the business use of the property, and often the number of business patrons. Office buildings, shopping centres, nightclubs, hotels, certain warehouses, some apartment complexes as well as vacant land that have the potential for development into these types of buildings can all be grouped as commercial land use (Thomson, 2013).

\subsection{Institutional Uses}

Karen, (1994) was of the fact that institutional land use includes government administrative offices and facilities, military installations, correctional facilities, religious, that is, buildings and grounds occupied by churches and other structures used for meetings, worship, and activities of religious groups. Also, health institutions include public or private clinics for medical or mental health treatment or diagnosis which are located within the communities that they serve and land occupied by facilities that provide a variety of health care and physical or mental rehabilitation services to residents, including hospitals, medical clinics, doctors' offices, medical laboratories, nursing homes, and sanitariums, while the surrounding grounds, parking areas, and support buildings associated with these facilities are included. The land occupied by the educational buildings or other uses associated with educational institutions, to include all public and private educational institutions, including pre-schools for children below kindergarten age, public or private daycare, elementary and secondaryl high schools, colleges, universities, trade and vocational schools, and other educational institutions. Harrison and Garland (2001) described institutional land use to consists of medical and health care service which include, hospitals and convalescent home and other medical and health services e.g. dentist, doctor, chiropodist, and optician. Also to include places of worship as in Churches, mosques and synagogues, while educational land uses connected with educational establishments which among others include schools, colleges, higher and further education centres, universities and other specialized learning places. Other institutional land use includes community protection and justice administration services e.g. police stations, fire stations, coastguard and lifeboat stations, and law courts, community protection and detention centres, Community meeting places club, public sanitation facilities and animal welfare facilities. 


\subsection{Recreational Uses}

This comprise of indoor and outdoor land and facilities developed to support assembly, recreational, cultural, or entertainment activities which include indoor public or private facilities for cultural activity, recreation, and public assemblies, such as planetariums, civic centres, theatres, auditoriums, indoor tennis courts, field houses, and enclosed stadiums. Outdoor cultural, public assembly, and recreational lands (and their accompanying incidental buildings) including museums and other indoor cultural activities that include facilities libraries, museums, art galleries, planetariums, aquariums, nature or craft exhibits, historic buildings, and historical monuments (Karen,1994). Harrison and Garland (2001) highlighting recreational land use to include outdoor amenity and open spaces, amusement and show places libraries, museums and galleries, sports facilities and grounds, holiday parks and camps and allotments and city farms.

\subsection{Agricultural Uses}

Agricultural land use is related to the production of food and maybe broadly defined as land used primarily for the production of farm commodities. Karen, (1994) asserted that agricultural land use are lands that are used for crops, grain and forage crops, pastureland, and idle fields in rotation to cultivated crops or pasture and also included land and buildings used for livestock's raising, poultry and other animal operations. The nature of agricultural land use depends on the type of crops and agronomic system which often resulted from intensity managed to a more organic system involving annual or perennial crop. Land with farmsteads, greenhouses, and horse training facilities are also included, while research facilities land use consists of land used for any cultivated land and associated facilities specifically used for research where the designation for research takes precedence over the specific crops being cultivated. Harrison and Garland (2001) agreed to the fact that agricultural land use includes land being used for horticulture, fruit growing, seed growing, dairy farming, the breeding and keeping of livestock (including any creature kept for the production of food, wool, skins or fur), the use of land as grazing land, meadowland, osier land, market gardens and nursery grounds, and the use of woodlands where that use is ancillary to the farming of land for other agricultural purposes and land under agricultural rotation whether for crops or grassland or left fallow (Adebayo, 2009; Azulaidin and Anwar, 2020).

\subsection{Transportation Uses}

Harrison and Garland (2001) viewed that transport land uses as land used for transport, tracks and ways, transport terminals, interchanges and car parks. The land is used for moving people and goods from one place to another. Karen, (1994) asserted that transport land use comprises of major transportation facilities, including those associated with ground, water, and air transportation, highways, railways, airports and seaports. Transportation land uses includes among other sidewalks, roads, highways, subways, streetcars, railroad tracks, freight yards, airports, marinas and any other land that is used for transportation.

\subsection{Water Bodies}

This includes all areas of surface water with no, or minimal, emergent vegetation land with a significant tree, shrub, or herbaceous cover which that are permanently, seasonally, or periodically swamped. All lakes, ponds, rivers, and streams that cover an area large enough to be delineated as the area features water bodies. Karen, (1994) suggested that wastewater land use is linked with the transport, storage, distribution, and 
collection of wastewater and land used for the collection and treatment of wastewater, public and private treatment plants, waste treatment ponds, drying beds, and pumping facilities. It also involves, land used for the storage, treatment, and distribution of public and private water supplies, water storage tanks and towers, treatment plants, pumping facilities. Harrison and Garland (2001) added that water land uses related to water storage and distribution places e.g. reservoirs, water towers and pumping stations, and also sewage disposal and treatment land use, including drains, pumping stations and sewage farms. Refuse land use connected with disposal facilities, including tips, landfill sites and disposal plants.

\subsection{Undeveloped Land}

Undeveloped land comprises of non-forested, non-agricultural land, areas of active or abandoned mines, quarries, and spoils areas (Karen, 1994). Harrison and Garland (2001) viewed that unused land consists of semi-natural areas of land which are not part of routine cultivations or grazing and which have never been used for development.

\section{Research Methods}

For the research, satellite and aerial imagery through Google earth was used and an administrative map of Obafemi Awolowo University as the base map. Data from Google Earth Pro, a virtual globe map and geographical information program, were compiled to estimate the uses of several classes of land in Obafemi Awolowo University (OAU). The administrative map and Google earth pro were used to identify the various land uses and determine their size in hectares. The Google earth pro and OAU map was subsequently used to enhance visual interpretation and aid the identification and mapping of the various land uses. Figure 2 shows the map of land classification in OAU, Figure 3 shows an aerial view of the OAU central campus while Figure 4 shows an aerial view of OAU staff quarters.

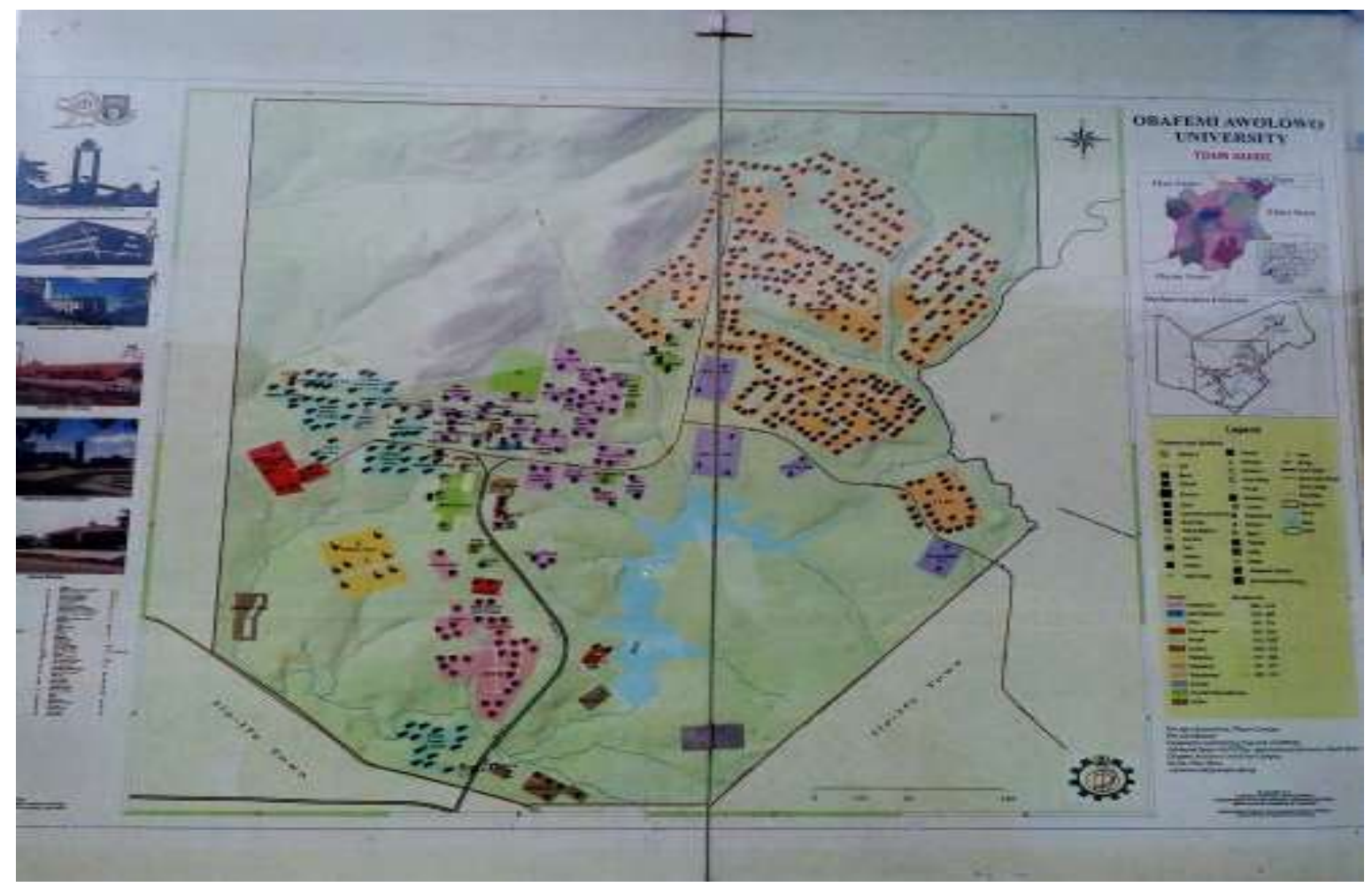

Figure 2. Map of Land Classification in $O A U$ 


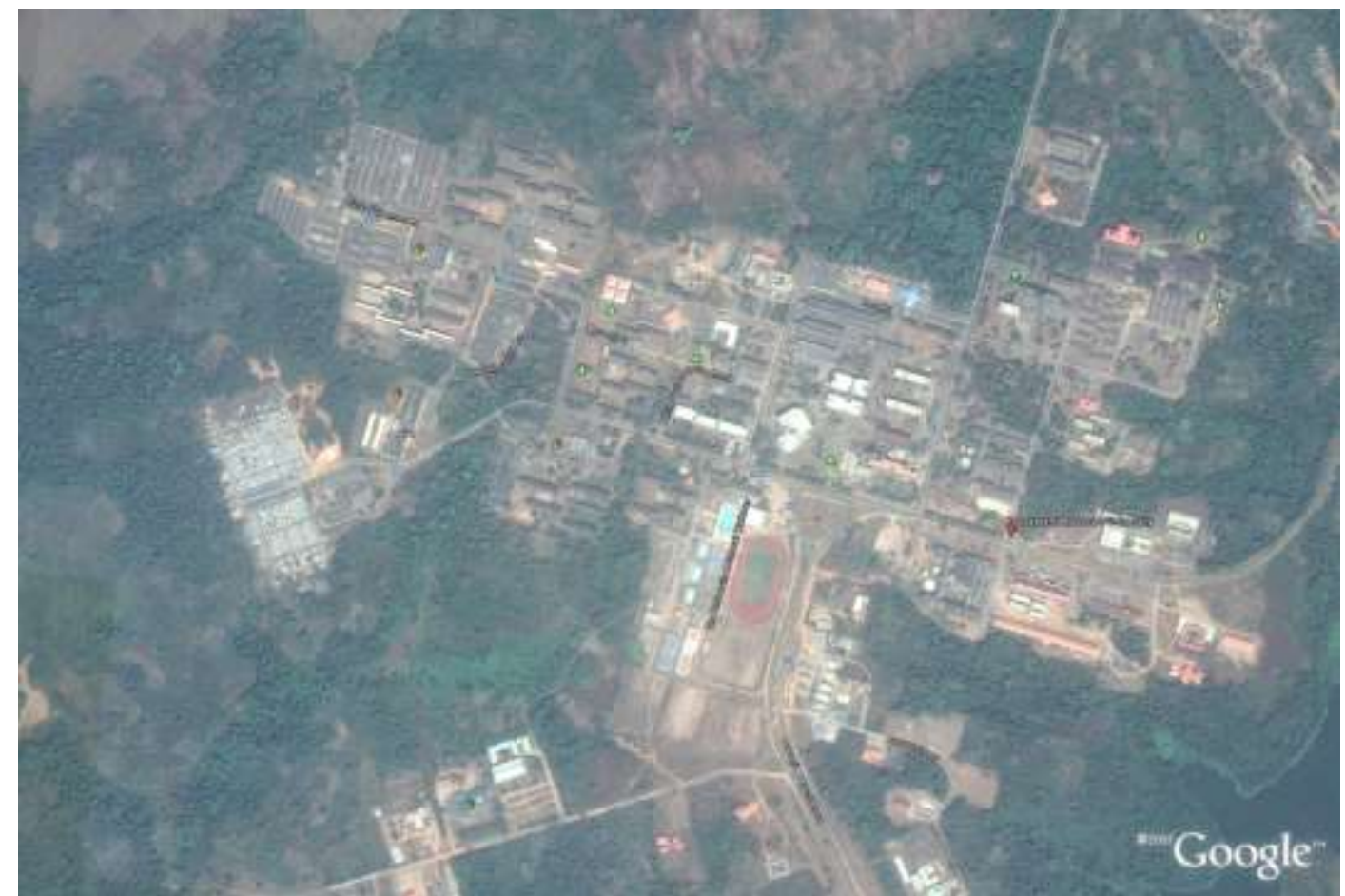

Figure 3. An aerial view of OAU showing the central campus

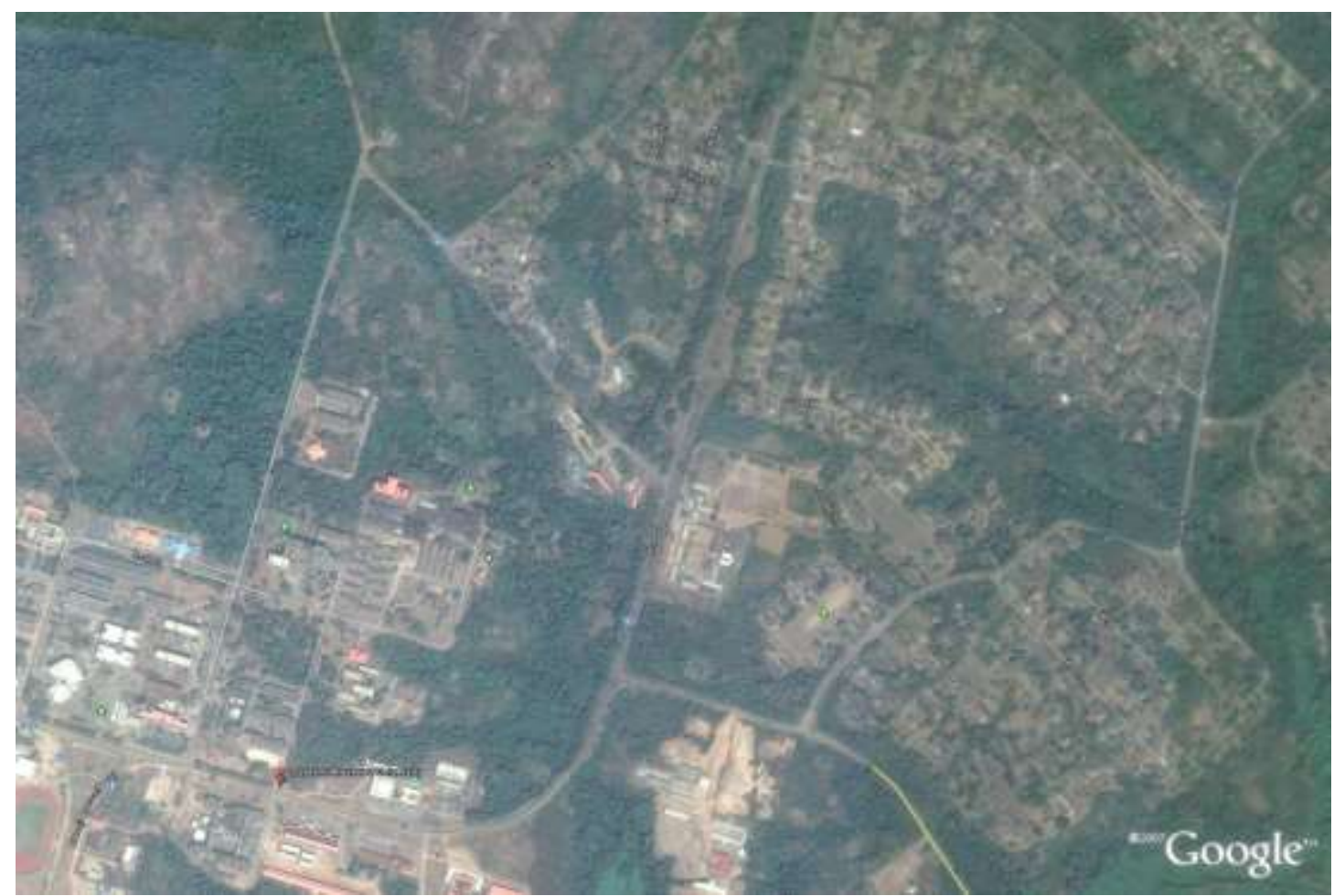

Figure 4. An aerial view of OAU showing the staff quarters

Also Since we are interested in land use classification system in Obafemi Awolowo University, a land-use classification system was developed considering only land-use types found in the institution (see Table 1). The proposed land use classification system for this research is presented below. 
Table 1. Land Use Classification System Used in this Research

\begin{tabular}{|c|c|c|c|}
\hline \multirow{2}{*}{$\begin{array}{l}1 \\
\mathrm{a} \\
\mathrm{b}\end{array}$} & \multirow{2}{*}{$\begin{array}{l}\text { Residential } \\
\text { Students Hall of Residences } \\
\text { Staff Quarters }\end{array}$} & 4 & Water Bodies \\
\hline & & 5 & \multirow{2}{*}{$\begin{array}{l}\text { Commercial } \\
\text { Central Market } \\
\text { Student Union Building }\end{array}$} \\
\hline 2 & Instituti & $\mathrm{b}$ & \\
\hline $\mathrm{a}$ & \multirow{7}{*}{$\begin{array}{l}\text { Administrative Bui } \\
\text { Faculty Buildings } \\
\text { Departmental build } \\
\text { Lecture theatres } \\
\text { Research Centres } \\
\text { Distance Learning } \\
\text { Religious Centre }\end{array}$} & $\mathrm{c}$ & Banking Areas \\
\hline $\mathrm{b}$ & & $\mathrm{d}$ & New Buka \\
\hline $\mathrm{c}$ & & $\mathrm{e}$ & OAU press \\
\hline d & & $\mathrm{f}$ & Ogunbanjo Hall \\
\hline $\mathrm{e}$ & & $\mathrm{g}$ & OAU Ozonized Water \\
\hline $\mathrm{f}$ & & $\mathrm{h}$ & NIPCO filling station \\
\hline $\mathrm{g}$ & & $\begin{array}{l}6 \\
\mathrm{a}\end{array}$ & $\begin{array}{l}\text { Recreation } \\
\text { Sport Complex }\end{array}$ \\
\hline \multirow{3}{*}{$\begin{array}{l}3 \\
\mathrm{a} \\
\mathrm{b} \\
\mathrm{c}\end{array}$} & \multirow{3}{*}{$\begin{array}{l}\text { Transportation } \\
\text { Road Networks } \\
\text { Car Parks } \\
\text { Pedestrian Walkway or Sideways }\end{array}$} & $\mathrm{b}$ & Parks and Garden \\
\hline & & 8 & Agriculture \\
\hline & & 9 & Other Uses \\
\hline
\end{tabular}

\section{Results and Discussion}

\subsection{Land Uses in Hectares in Obafemi Awolowo University}

The university has a land area of about 5,608 hectares out of which about 1,011 hectares constitute built-up areas, about 1,216 was set aside for Teaching and Research Farm, and the remaining 3,379 hectares is still undeveloped amounting to 60 per cent (see Table 2). A larger percentage is still undeveloped which constitute about 3379 hectares, which is 60 per cent of the entire land area, taking up more than half of the total classes. Approximately 1216 hectares were set aside for Teaching and Research farm which represent about 22 per cent of the university land (see Table 2). It comprises the farm centre and area for the teaching and research activities in the Department of Agricultural Economics, Agricultural Extension and Rural Development, Animal Sciences, Crop Production, Soil Science and Family Nutrition and Consumer sciences. Figure 5 shows the land areas in hectares at Obafemi Awolowo University.

Table 2. Land Areas in Hectares in Obafemi Awolowo University

\begin{tabular}{|l|l|l|}
\hline Land Uses & Land area in Hectares & \% of Total Land Area \\
\hline Built-up areas & 1011 & 18 \\
\hline Agriculture & 1216 & 22 \\
\hline Undeveloped areas & 3382 & 60 \\
\hline Total & 5609 & 100 \\
\hline
\end{tabular}




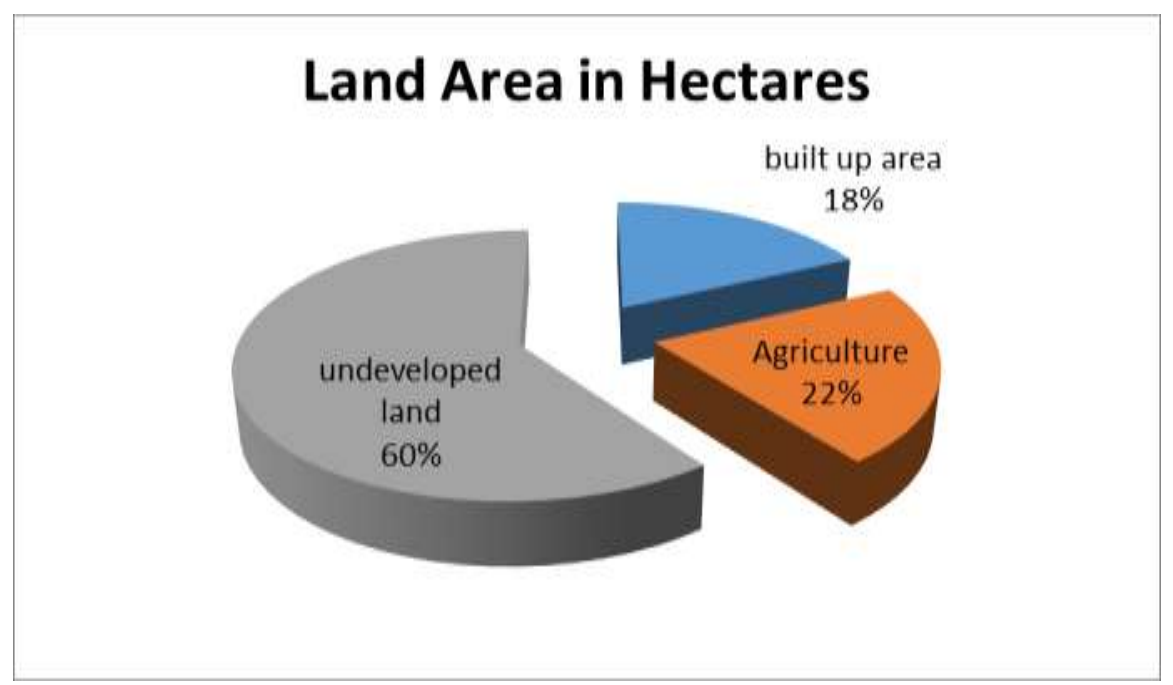

Figure 5. Land Areas in Hectares in Obafemi Awolowo University

\subsection{Major Land Uses in Obafemi Awolowo University}

The built-up area in Obafemi Awolowo University had a total land area of about 1011 hectares, which is 18 per cent of the entire land area in the institution. This is allocated among a variety of uses (see Table 3). As at the time of this research, the largest shares of the built-up areas were allocated to residential land uses with 45.18 per cent of the land use. A total of 25.42 per cent was allocated to institutional uses while commercial had 3.79 per cent, transportation had 5.57 per cent, water bodies had 8.26 per cent and recreational use accounted for 0.31 per cent while a variety of other uses including, schools, and cemetery comprised the remaining 11.47 per cent. Figure 6 the major uses of land in hectares in Obafemi Awolowo University.

Table 3. Major Land Uses in Hectares in Obafemi Awolowo University

\begin{tabular}{|l|l|l|}
\hline Land Uses & Land area in Hectares & \% of Total Land Area \\
\hline Residential & 456.74 & 45.18 \\
\hline Institutional & 257.02 & 25.42 \\
\hline Commercial & 38.36 & 3.79 \\
\hline Transportation & 56.33 & 5.57 \\
\hline water bodies & 83.5 & 8.26 \\
\hline Recreation & 3.08 & 0.31 \\
\hline Other uses & 115.97 & 11.47 \\
\hline Total & 1011 & 100.00 \\
\hline
\end{tabular}




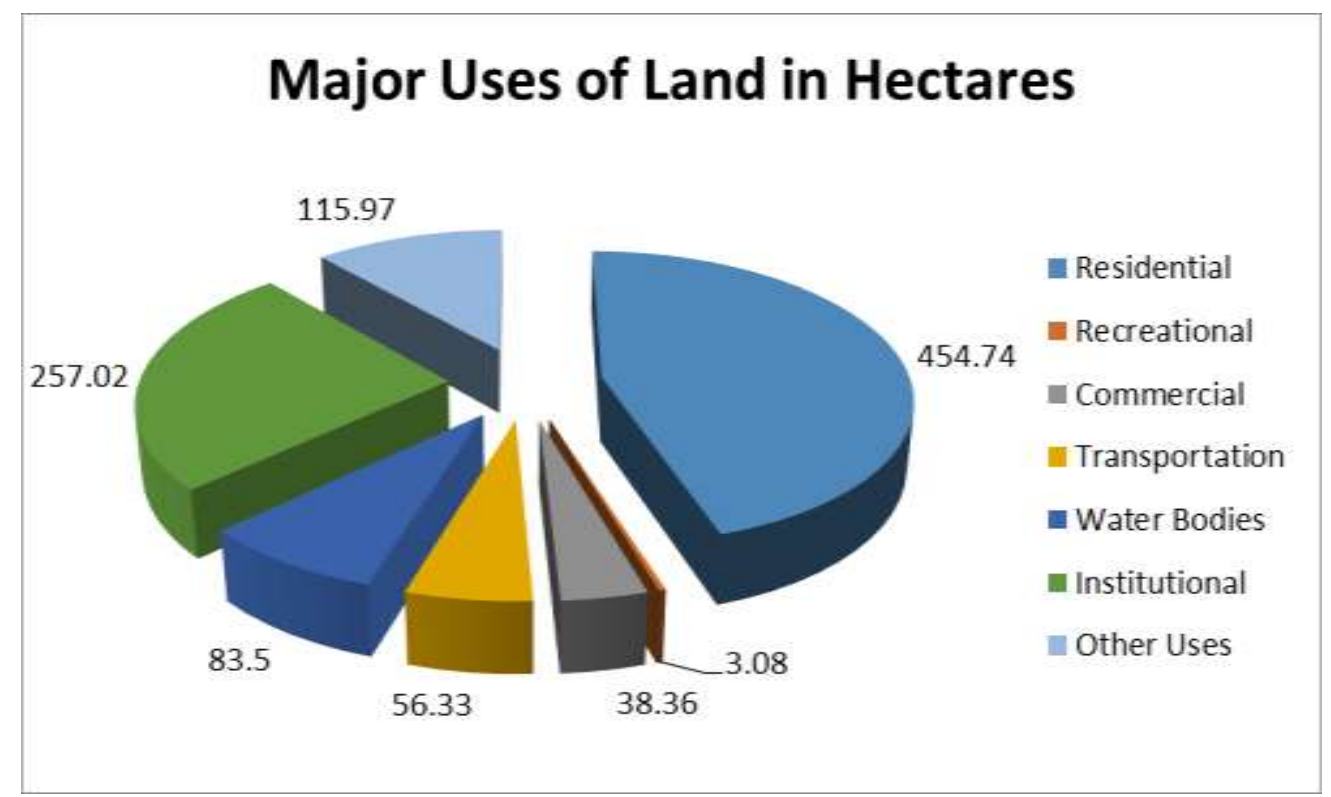

Figure 6. Major Uses of Land in Hectares Obafemi Awolowo University

Residential land use had 456.74 hectares representing 45.18 per cent (see Table 3 ) representing the largest share of OAU built-up land. Two types of residential development can be identified in OAU; these are the student's hall of residences and staff quarters. Students hall of residences includes Adekunle Fajuyi hall of residence, Akintola hall of residence, Alumni hall of residence, Angola hall of residence, ETF hall of residence, Female hostel, Moremi hall of residence, Mozambique hall of residence, Obafemi Awolowo hall of residence and Post Graduate hall of residence. Also, we have Residential Junior Staff Quarters and Residential Senior Staff Quarters. Also, there are light mixed uses that comprised commercial activities with the residential uses; for example, the presence of small shops in each hall of residence where daily needs could be bought.

The study shows that the Land uses for institutional purposes comprises; lecture theatres (1000 capacity Sitter, Geology, Amphitheatre) Departmental buildings (Local Government Studies, Dramatic Art, Biological Sciences, Mathematics among others), Faculty buildings (Environmental Design and Management, Law, Pharmacy, Social Sciences and Technology), Post Graduate College, Administrative buildings, Research centres, Distance Learning, religious centre, the school Library, which amounted to 257.02 hectares (see Table 3). These areas, reflecting a variety of intensity of use, represented 25.42 per cent of all developed land in the institution. Throughout history, OAU has pursued strong commitment in the highest level of scientific research and teaching through the following research centres; Centre for Energy Research and Development (CERD), National Centre for Technology Management (NACETEM), Regional Centre for Training in Aerospace Surveys (RECTAS), Centre for Space Science and Technology Education in Africa (ARCSSTE).

Commercial Land use is of an estimated 38.36 hectares of the developed areas, accounting for 3.79 per cent of all built-up areas (see Table 3). The main commercial activities in OAU are located at the central market with some commercial activities concentrated at the Student Union building. Also within OAU, there are other commercial activities located at New Buka, banking area (which accommodate most of the banks on campus), OAU press, Ogunbanjo hall, OAU ozonized water, Banks, NIPCO filling station, which are patronized majorly by the students and staffs of the institution. Transportation Land use in OAU includes road network, pedestrian walkways or sidewalks and car parks, 
The transportation land use in OAU covers 56.33 hectares of land use and accounts for about 5.57 per cent of the total developed area (see Table 3). Water bodies accounted for an estimated 83.5 hectares, about 8.26 per cent of the institution built-up land area (see Table 3).

The staff and students of OAU play different sorts of games to enjoy themselves and for their relaxation. This accounted for the reason why recreational facilities were mixed with residential land uses within the campus. Some of the renowned recreational centres which provide relaxation for staffs and students include National Historical Museum, Sports Complex, Parks and Garden, Golden Jubilee Garden and Zoo. In all, recreational facilities in OAU occupy approximately 3.08 hectares of land which accounts for 0.31 per cent of the total land use (see Table 3). The land uses under other land uses includes the estimated 115.97 hectares which represent 11.47 per cent of the developed areas (see Table 3). They include Powerhouse, Maintenance, Oxidation centre, OAU cemetery, schools (Moremi high school, OAU staff school, OAU International School, OAU Primary School) among others.

\section{Conclusion}

This study investigated the major uses of land in tertiary institutions using OAU as the case study. It can be deduced from the findings of this research that the total landed area of OAU is 5,609 hectares. Apart from the undeveloped area which constitutes more than half of the total land area with 3382 hectares (60 per cent), and a total of 1,216 hectares of land set aside for agriculture purposes and research, the major land use is Residential at 456.74 hectares (45.18 per cent); Institutional use at 257.02 hectares (25.42 per cent); other uses at 115.97 hectares (11.47 per cent); Water bodies at 83.5 hectares (8.26 per cent); Transportation at 56.33 hectares (5.57 per cent); commercial at 38.36 hectares (3.79 per cent); and Recreation at 3.08 hectares (0.31 per cent), the least proportion of land use. The inferences from this study show that the institution still has more than half of the total hectares unused which can be used in future in the area of recreational uses ( such as open spaces, greening areas, sporting area among other) commercial uses that constitute the lowest percentage of land used in the present form.

The study suggested land use monitoring unit of the institution should be strict with land uses and comply with the master plan of the university. Various land uses should be monitored, regulated, and controlled by the various relevant planning and monitoring agencies of the university. Furthermore, guidelines on land use should have Institutional, commercial and residential area clearly defined to avoid unselective uses as a result of development. It is significant to safeguard that the law guiding land use is correlated and obligatory with the master plan of the university to avoid uncontrolled and irregular land uses in the university. 


\section{References}

(FMH\&UD) (2003). Federal Ministry of Housing and Urban Development, Sustainable Human Settlements Development: National Urban Strategies. Petral Digital Press, Abuja.

Adebayo, (2009). Impact of Urban Land Use Changes on Property Values in Metropolitan Lagos: Medwel

Adetokunbo, L. (2010). Skilled -Oriented Training; Essential Public Health Service.

Adetunji M.A. (2014) Urban Land use Characteristics and Trip Generation Patterns in a Developing Economy: A Case Study of Ilesa, Osun State, Nigeria. Academic Journal of Interdisciplinary Studies, MCSER Publishing, Rome-Italy, Vol 3 No 4

Aribigbola A. (2008) Improving Urban Land Use Planning and Management in Nigeria: The Case of Akure, Theoretical and Empirical Researches in Urban Management, Year 3, Number 9, 2008

Azulaidin, Anwar (2020). Factors Affecting the Growth of the Agricultural Sector in Langkat Regency; Konfrontasi Journal: Culture, Economy and Social Changes, 7 (4) December 2020, PP. 264-274 ISSN: 1410-881X (Print), 2716-2095 (Online).

Famoriyo, S. (2007). land tenure, land use and land acquisition in Nigeria, Institute of Agricultural Research, Ahmadu Bello University, Zaria, Nigeria

Harrison, A.R. and Garland, B. (2001). The National Land Use Database: building new national baseline data of urban and rural land use, Proceedings of the AGI Conference at GIS 2000, Olympia, London, $\mathrm{t} 2.5 .1-\mathrm{t} 2.5 .11$.

Izharsyah, J. R. and Lubis, F.H. (2020). Analysis of Masterplan in Medan City Determining the Strategic Area (KSK) Social Culture Fields in Medan. Budapest International Research and Critics Institute-Journal (BIRCIJournal).Volume 3, No. 4, PP. 2821-2834 e-ISSN: 2615-3076. P-ISSN: 26151715

Karen, .S (1994). A Standard Classification System for the Mapping of Land Use and Land Cover.

Njoku J. and Kumolu C. (2014). 53 years after, OAU set up 200 member forum to review university's master plan, Tuesday Vanguard, print edition of February 4, 2014, www.vanguardngr.com/2014/02/53-years-oau-sets-200-members-forum-reviewuniversitys-master-plan/ Access date 27th August 2020

Thomson, R. (2013). Find Law Guide to Online Fraud and Identity Theft. www.lawyers.findlaw.com/lawyer/firm/administrative-law/thomson/georgia.

Access date 27th August 2020

Zhan Q., Molenaar M. and Gorte B. (2000). Urban Land Use Classes with Fuzzy membership and Classification based on Integration of Remote Sensing and GIS. International Archives of Photogrammetry and Remote Sensing 33 (part B7), $1751-1758$ 